\title{
Unspoken demands for farm technology
}

\author{
Jeffery Bentley ${ }^{1}$, Claudio Velasco ${ }^{2}$, Félix Rodríguez ${ }^{3}$, Rolando Oros $^{4}$, Rubén Botello ${ }^{4}$, \\ Morag $\mathrm{Webb}^{5}$, André Devaux ${ }^{6}$ and Graham Thiele ${ }^{7 *}$ \\ ${ }^{1}$ International Consultant, Cochabamba, Bolivia; ${ }^{2}$ INNOVA Project, Cochabamba, Bolivia; ${ }^{3}$ College of Agronomy, \\ Universidad Mayor de San Simón, Cochabamba, Bolivia; ${ }^{4}$ PROINPA Foundation, Cochabamba, Bolivia; ${ }^{5}$ Glyndwr, \\ Carrog, Corwen, Denbighshire, UK; ${ }^{6}$ Papa Andina Programme, CIP, Lima, Peru; and ${ }^{7}$ Papa Andina Programme, \\ CIP, Lima, Peru
}

\begin{abstract}
For three years in Bolivia (2002-2005) the INNOVA Project finished researching several technologies for sustainable agriculture, started by earlier DFID-funded projects. Before INNOVA started critics suggested that these technologies should be discarded in favour of a demand survey. Instead, INNOVA kept the existing technologies, but judged the demand for them with several methods (CIAL, sondeo technology fair, and others). INNOVA found that there was demand for some of the technologies, but that a survey would have missed much of the demand, which is implicit. That is, people are not initially aware of all their problems or of all the possible solutions. Over the years, farmers made more specific, sophisticated demands on the technologies, which evolved as a result. Demand and supply of farm technology are like two sides of an unfolding conversation.
\end{abstract}

Keywords: demand for new technology, technology supply, Bolivia, participatory research methods

\section{Introduction}

Smallholder farmers need new technologies from the formal sector if they are to stay competitive and sustainable in a rapidly changing world (Tudge, 2004). There is a growing awareness among researchers and policy-makers that research should be 'demand-led', meaning that farmers should help set the research agenda (Beye, 2002; Royal Society, 2004). 'Demand' for research is not the same as the market demand for goods and services. In competitive markets, prices send signals between buyers and sellers about the demand of goods and services. Most of the products of agricultural research, such as IPM principles, or new tillage practices etc., are public goods which can be freely and widely shared with no loss in their value. Many of them

\footnotetext{
*Corresponding author. Email: g.thiele@cgiar.org
}

cannot be sold, so no private market will promote them. ${ }^{1}$ At the same time, smallholder farmers in tropical countries have little contact with researchers and have little scope for expressing demand for research (e.g. new farm tools, crop varieties or pest control techniques) through non-market means. Participatory diagnoses have been proposed as ways to see what people want (Bellon, 2001; Gill, 2002; Horne and Stür, 2005), often with an emphasis on easing the adoption of technologies (Smale \& De Groote, 2003). In Vietnam, researchers interviewed farmers, learning the history of fruit trees, and how farmers managed them, which helped

\footnotetext{
${ }^{1}$ Public goods in the economic literature are defined as those goods which are non-excludable and non-rivalrous (Dalrymple, 2005). The classic example of a public good is a lighthouse, no user can be excluded from access to the good (non-excludable) and however many ships make use of the light signal there is no reduction in its value (non-rivalrous).
} 
scientists understand why some farmers were getting more serious pest problems. Only then could researchers make detailed recommendations, in a way which farmers would accept (Van Mele \& Van Chien, 2004). As this example shows, farmer demand co-evolves with research. Demand for research is not like an object in the real world, which can be discovered; rather it is more like one side of a conversation which will only unfold if there is someone else to talk to.

This paper discusses a three-year experience to describe and meet farmer demand in Bolivia. In 2001, Bolivian agricultural scientists had many technologies which were considered almost ready to disseminate. These were the fruit of several earlier projects funded by DFID in potato growing areas. However, the Bolivian Agricultural Technology System (SIBTA) had been established the previous year: it was explicitly 'demand-led', which presented the scientists with new challenges.

SIBTA was a public-sector, competitive-funding organisation, following similar models created elsewhere in Latin America and an emerging paradigm for national agricultural research systems (Byerlee, 1998; Hall et al., 2003). SIBTA replaced IBTA (the Bolivian Institute of Agricultural Technology); IBTA was disbanded in 1998 (Gandarillas et al., 2007). Competitive bidding seeks to improve the accountability and relevance of agricultural research. Calls for research and funding come from farmers, in written petitions, preferably from organized groups (cooperatives, farm unions, indigenous organizations, etc.) and are elicited from farmers, as a 'raising of demands' (levantamiento de demandas). Most of SIBTA's work is channelled through four Foundations which manage extension projects known as PITAs.

In this context, policy-makers in $\mathrm{La} \mathrm{Paz}$ suggested that technologies which researchers had already developed should be abandoned and a fresh start made, by collecting demand from smallholder farmers. However:

- First, capturing farmer demand may not be as simple as SIBTA's architects believe. The idea of 'collecting demand' supposes that farmers know their needs, and will voice them. It also supposes that farmers are aware of potential technical options that could respond to this demand, the costs, and the pros and cons of each one.
- Second, what should be done with research that is already underway and in which much time and money has already been invested?

Learning farmer demand requires a deeper interaction with farmers than a survey, petition or a village meeting. Besides, the scientists insisted that their nearly ready technologies had been designed in response to smallholder demand. Finally, after much heated discussion, the researchers and various colleagues (including the authors) developed the INNOVA project to gauge and respond to farmer demand, even for technology that already existed (Bentley et al., 2004). INNOVA was implemented through three partner organizations which were involved with DFID before SIBTA (see Table 1). INNOVA was managed by the regional partnership programme of the International Potato Centre (CIP), known as Papa Andina.

INNOVA worked with farmers in pilot areas in three distinct agro-ecozones, hundreds of kilometres apart (the high valleys of Cochabamba in central Bolivia, the low valleys of Santa Cruz in the east and the high plains or Altiplano of $\mathrm{La} \mathrm{Paz}$ in the west). INNOVA lasted for three years (2002-03,

Table 1 INNOVA partner organizations

\begin{tabular}{|l|l||}
\hline Institution & \multicolumn{1}{|c|}{ Brief description } \\
\hline CIAT/Santa Cruz & $\begin{array}{l}\text { The Centre for Tropical } \\
\text { Agricultural Research, } \\
\text { Santa Cruz, a public } \\
\text { agricultural R\&D } \\
\text { institution affiliated with } \\
\text { the prefecture of Santa } \\
\text { Cruz Department, not to } \\
\text { be confused with the } \\
\text { international centre in } \\
\text { Colombia }\end{array}$ \\
\hline UMSS & $\begin{array}{l}\text { The Public University of } \\
\text { San Simón, } \\
\text { Cochabamba, which } \\
\text { includes an agricultural } \\
\text { college }\end{array}$ \\
\hline PROINPA Foundation & $\begin{array}{l}\text { A private non-profit } \\
\text { institution for research } \\
\text { on Andean crops, which } \\
\text { evolved out of the IBTA } \\
\text { potato programme, with } \\
\text { support from the Swiss } \\
\text { Agency for Development } \\
\text { and Cooperation (SDC) }\end{array}$ \\
\hline
\end{tabular}


2003-04, 2004-05). Its goal was to find methods to capture farmer demand for research, and to refine technologies that had been recently invented.

\section{Starting technologies}

In 2002, INNOVA proposed validating 10 technologies with farmers (Table 2), and began developing methods to compare this supply of technology with farmer demand, as discussed in the following section.

\section{Methods to create technology and adjust it to demand}

The researchers used several methods (described below) to hone their technologies, always with farmers, never on-station. INNOVA adapted most of these methods from existing ones. What was novel was a coherent set of methods for linking the supply and demand for technology (Doug Horton, personal communication).

Table 2 Supply of technology at the start of INNOVA

\begin{tabular}{|c|c|c|}
\hline Family of technologies & Technology proposed, 2001 & Brief description \\
\hline \multirow[t]{4}{*}{ Fodder and soil conservation } & 1. Improved fallow & $\begin{array}{l}\text { Mixtures of purple clover (legume: } \\
\text { Trifolium pratense) with grasses (Lolium } \\
\text { perenne, Festuca arundinaceae, Dactylis } \\
\text { glomerata) to plant after harvesting oats } \\
\text { or barley, as the field enters fallow, to } \\
\text { produce fodder and manage weeds. }\end{array}$ \\
\hline & 2. Grains-plus-legumes & $\begin{array}{l}\text { Mixes of legumes (vetch, purple clover) } \\
\text { with grains (oats, barley) for fodder, to } \\
\text { conserve soil and water, control pests, } \\
\text { diseases and weeds and stabilize yields. }\end{array}$ \\
\hline & 3. New fodders & $\begin{array}{l}\text { Some } 14 \text { varieties of several species of } \\
\text { legumes and grasses, planted in small } \\
\text { demo plots called 'pasture gardens'. }\end{array}$ \\
\hline & 4. Phalaris grass & $\begin{array}{l}\text { Live barriers of phalaris grass (Phalaris } \\
\text { tuberoarundinacea) planted in rows for } \\
\text { soil conservation. The live barriers form a } \\
\text { wall that traps runoff, slowly forming a } \\
\text { terrace. The grass is good fodder. }\end{array}$ \\
\hline \multirow[t]{3}{*}{$\begin{array}{l}\text { IPM (integrated pest } \\
\text { management) }\end{array}$} & $\begin{array}{l}\text { 5. Chicken manure for } \\
\text { nematodes }\end{array}$ & $\begin{array}{l}\text { Integrated management of the nematode } \\
\text { Nacobbus aberrans by applying chicken } \\
\text { manure to the soil. }\end{array}$ \\
\hline & 6. Potato IPM & $\begin{array}{l}\text { IPM of potato pests and diseases in the } \\
\text { low valleys (Santa Cruz). Some } 10 \text { ideas } \\
\text { including insecticides and plant extracts } \\
\text { to kill insect vectors of disease (aphids, } \\
\text { whiteflies etc.), control of tuber moth in } \\
\text { the field and fungicides for Rhizoctonia. }\end{array}$ \\
\hline & 7. Herbicide for purple nut sedge & $\begin{array}{l}\text { Weed management (Cyperus rotundus). } \\
\text { Trials of the herbicide glyphosate. }\end{array}$ \\
\hline \multirow[t]{3}{*}{ Animal traction and tillage } & 8. Improved tillage & $\begin{array}{l}\text { Several ploughs had been designed, } \\
\text { and a few trials were needed to learn the } \\
\text { best ploughing dates. }\end{array}$ \\
\hline & 9. Adoption of implements & $\begin{array}{l}\text { Promote adoption of animal-drawn } \\
\text { implements. }\end{array}$ \\
\hline & 10. Home remedies for cows & $\begin{array}{l}\text { Better nutrition for livestock, remedies } \\
\text { made from local plants to kill cattle } \\
\text { parasites. }\end{array}$ \\
\hline
\end{tabular}


INNOVA coined the idea of explicit and implicit demand. Explicit demands are the ones that people recognize and can express loud and clear ('We need more grass for our sheep in the dry season'). Implicit demands are for problems that the people themselves do not recognize (they will not demand control of potato viruses if they do not know that viruses exist), or for techniques which they have not imagined (e.g. they did not demand metal ploughs until they saw them). INNOVA used the following methods to study demand.

\section{CIAL and GET}

CIALs are groups of about five local people who conduct field trials with a few replications, and uncomplicated trial designs on topics the communities have agreed upon, presenting the final results back to the community (Ashby et al., 2000; Braun et al., 2000; Thiele et al., 2005; Pretty, 2002). Before INNOVA, both PROINPA and CIAT/Santa Cruz had already organized several CIALs. In other areas, INNOVA used the GET (technology evaluation group). A GET is like a CIAL, except that instead of asking farmers to define their research topics, the agronomists present their research topics and the community decides which to try. The GET and the CIAL both evaluate the technologies with committees of farmers, who use simple tables with flipcharts ('participatory evaluations') to register and analyse committee members' preferences for different technologies, and for which characteristics (Ashby, 1992). INNOVA used CIALs and GETs during all three years. An unanticipated advantage of the CIALs and GETs was that they helped INNOVA with the other methods described below. The committee members were like promoters (Bunch, 1982), suggesting that most methods for working with rural communities can be enhanced by personal contacts between researchers and some individual community members.

\section{Back-\&-forth (Ir-y-Venir)}

This is a method that PROMETA (part of UMSS) had developed and used previously, which was used during all three years of INNOVA. Researchers take an implement, e.g. a plough, to the field. They try it with the campesinos who suggest changes.
The mechanical engineer redesigns the implement, and the team takes it back to the field, until people are satisfied with it. In the final stages, PROMETA may leave an implement in a community so they can try it for several days. For example in 2003, INNOVA showed metal ploughs that had been developed in the valleys to campesinos in the Altiplano. They liked the plough, but asked for wider wings, to heap more earth around the potato plants. They also said the $13 \mathrm{~kg}$ plough was too heavy for their oxen, which are smaller than the ones in the valleys. INNOVA returned with a lighter, $8.5 \mathrm{~kg}$ plough, but it was too fragile, and could not work the rocky soil of the Altiplano. By 2004, INNOVA returned with a heavier plough, 10.5 kilos, with a stronger, sharper point. It worked well and people began to buy it.

\section{Sondeo}

The sondeo (literally 'sounding', the nautical term for finding the depths of the water) is known by its Spanish name even in English-language literature (Hildebrand, 1981). It involves six researchers going to the field for a week to observe farms and talk to farmers. Some of the partner organizations had used the sondeo for several years. CIAT started using the sondeo in the 1980s and PROINPA used it in the 1990s. INNOVA used a sondeo early in the first year (2002-03), but changed it, making it shorter (two days instead of six), going to one community in each of three regions (instead of many communities in a single region) and added a final session to discuss the results with the community (Bentley et al., 2004). Semi-structured interviews on crops, pests, livestock etc. led to ample descriptions of local agriculture, including problems and demands.

INNOVA's technologies fit reasonably well with the explicit demands voiced in the sondeo. For example, the farmers said they wanted more fodder for their cows, oxen and sheep (Bentley et al., 2004), and four technologies were for fodder (Table 3).

However, there was little explicit demand for nematode control, improved tillage, animal traction or soil conservation, which were all important for researchers in INNOVA (Table 2). This does not mean that the technologies were trivial. Nematodes are a serious pest in Bolivia, even though they are so 
Table 3 Summary of INNOVA's supply of technology, versus farmers' demands

\begin{tabular}{|c|c|}
\hline Technology supply & $\begin{array}{l}\text { Main demands from the } \\
\text { sondeo (Nov 2002-Jan } \\
\text { 2003) }\end{array}$ \\
\hline 1. Improved fallow & $\begin{array}{l}\text { Fodder: Altiplano, high } \\
\text { valleys }\end{array}$ \\
\hline 2. Grains-plus-legumes & $\begin{array}{l}\text { Fodder: Altiplano, high } \\
\text { valleys }\end{array}$ \\
\hline 3. New fodders & $\begin{array}{l}\text { Fodder: Altiplano, high } \\
\text { valleys }\end{array}$ \\
\hline $\begin{array}{l}\text { 4. Phalaris grass for soil } \\
\text { conservation }\end{array}$ & $\begin{array}{l}\text { Soil conservation was } \\
\text { not an explicit demand. } \\
\text { Later, INNOVA adapted } \\
\text { phalaris, emphasizing it } \\
\text { more as fodder }\end{array}$ \\
\hline $\begin{array}{l}\text { 5. Chicken manure for } \\
\text { nematodes }\end{array}$ & $\begin{array}{l}\text { Was not an explicit } \\
\text { demand }\end{array}$ \\
\hline 6. Potato IPM & $\begin{array}{l}\text { Several pests and } \\
\text { diseases, especially } \\
\text { potato late blight (all } 3 \\
\text { areas) }\end{array}$ \\
\hline $\begin{array}{l}\text { 7. Herbicide for purple } \\
\text { nut sedge }\end{array}$ & $\begin{array}{l}\text { Weeds, especially purple } \\
\text { nut sedge (low valleys) }\end{array}$ \\
\hline 8. Improved tillage & $\begin{array}{l}\text { Was not an explicit } \\
\text { demand }\end{array}$ \\
\hline $\begin{array}{l}\text { 9. Adoption of } \\
\text { implements }\end{array}$ & $\begin{array}{l}\text { Was not an explicit } \\
\text { demand }\end{array}$ \\
\hline \multirow[t]{2}{*}{$\begin{array}{l}\text { 10. Home remedies for } \\
\text { cows }\end{array}$} & $\begin{array}{l}\text { Various diseases of } \\
\text { several livestock species } \\
\text { (all areas) }\end{array}$ \\
\hline & Irrigation (all 3 areas) \\
\hline
\end{tabular}

difficult to observe that smallholders tend to be unaware of them unless the little worms are brought to farmers' attention (Bentley et al., 2003) Campesinos seldom complain of soil erosion, even when it is serious and chronic, but may show concern over extreme gulley erosion (Thiele \& Terrazas, 1998).

\section{Stratified sondeo}

A study funded by SDC found that almost everyone in Bolivia is poor (Quiroga et al., 1999). So the real question is not if the campesinos are poor, but if they are all equally poor, and if they all have the same needs for innovations. The study indicated more poverty in the Altiplano than in the low valleys. In three of the municipalities where
INNOVA worked, the rate of poverty was $98 \%$ (in Umala, on the Altiplano), 97\% (in Tiraque in the high valleys) and $85 \%$ (in Comarapa in the low valleys) (Quiroga et al., 1999). The $15 \%$ who are not poor tend to live nearest to the highway. They are more visible, have more contacts, more time and may be more likely to collaborate with INNOVA. So after the first sondeo, discussed above, INNOVA planned a stratified sondeo to distinguish between the demands of the poor, the poorer and the poorest. In Tanzania and Ethiopia, researchers held meetings to ask farmers to rank demands by income groups. Wealthy farmers were more concerned about the shortage of grazing land in Ethiopia, because they had more cattle. The poor were more concerned about access to irrigation water in Tanzania because the wealthy had the water. But many issues were of concern to most community members (e.g. declining soil fertility, deforestation, deteriorating water quality (German et al., 2005).

INNOVA conducted a stratified sondeo in four communities the second year (December 2003March 2004), identifying economic levels with wealth ranking (see Grandin, 1988). The stratified sondeo showed some differences between the 'rich' and the poor, e.g. on the Altiplano, the poorest felt most strongly the shortage of irrigation water. In the high valleys the least poor were the most concerned about the high price (\$50) of metal ploughs. And in the low valleys the poor were not interested in the problems of cattle or fruit trees. However, the poorest shared many demands with their wealthier neighbours (e.g. everyone wanted to control diseases of potato: a staple food of the Andes). But the stratified sondeo annoyed the local communities, which have a sense of moral equality. All community members are regarded as equal, even though they are well aware of wealth differences and it was upsetting for them to see this differences made so starkly obvious, when the facilitators asked people of different economic levels to sit in different workgroups. INNOVA found that the communities have just a few relatively prosperous households, with more land than the others, and just a few very poor households, mainly of elderly people. Most households are of middle income: poor but not destitute, food producers with a small surplus to sell, much as scholarly studies have shown for the Peruvian Andes (Mayer, 2002). 
Local notions of equality may be a kind of polite fiction, but glossing over some economic differences helps avoid problems like envy among community members, and allows them to respect each other and work together. In the future it will be important to learn about local economic differences, and the various demands for research per each group, but in slightly more discrete ways, not by physically arranging the 'strata' into highly visible workgroups ('all the poor people over here').

\section{Technology fair (feria tecnológica or encuentro tecnológico)}

Before harvesting their field trials, the researchers and the CIALs and GETs showed the test plots to hundreds of their neighbours and to people from other communities. They divided the visitors into three to five more-or-less random groups, who visited each trial (in a bus or on foot), where the farmer-experimenter explained the technology. Some technologies were presented as stands, which were not as convincing as the ones shown in the field, but stands saved time. Each technology fair took about six hours, but they were fun, 'a party without booze'. They started with a sign-in, and a welcome by municipal authorities. After seeing the field trials and stands, there was an exit questionnaire, a big lunch and a farewell. They included other fun events, like music, skits or a football match. Besides the lunch, farmers were also provided transportation to the technology fair (in a chartered bus). The technology fair was inspired by the field day, with the difference that INNOVA used short questionnaires to see which technology people preferred. The one-page forms could be filled out in two minutes, and they asked which technologies people wanted to try (and why) and which technologies did they not like (and why not). At a typical fair, 12 to 14 project staff members gave the questionnaires to over 100 people. INNOVA held technology fairs the first year in one community in all three regions, in two regions the second year (Altiplano and low valleys), and in two the third year (Altiplano and high valleys). The first year, INNOVA also used voting, with small 'ballots' which farmers dropped into boxes representing each technology. However, this gave similar results to the short questionnaires (see Bellon, 2002 for another voting method) and in following years INNOVA just used short questionnaires.

Forage was an explicit demand, however during the first technology fair (2003) on the Altiplano the fodder trial of grains-with-legumes had been planted late and the plants were barely growing. Questionnaires showed that the farmers were not convinced (only $31 \%$ expressed interest). In the sondeo on the Altiplano, people demanded more forage; quinoa was a secondary demand. However, during the fair, people actually preferred quinoa to fodder. In part this was because a woman and man from the area showed a healthy field of quinoa (they had used chemical fertilizer, not a local practice) (see Figure 1a). People also liked quinoa perhaps because at a stand, agronomists gave a convincing talk, and handed out pieces of quinoa cake (see Figure 1b). People are attracted to well-presented technology, even if it is not high on their list of demands.

In the fairs, the farmers gave high scores to improved tillage and animal-drawn implements, even though these were not demanded in the sondeo. The technologies responded to implicit demands; people did not request the implements until seeing them. By the third year INNOVA knew how to show its techniques to best effect: in the field, with a thriving crop, explained by farmers in the local language (Spanish, Quechua or Aymara), and giving away little $(50 \mathrm{~g})$ bags of seeds, so farmers could try the new crops or varieties at home (see Figures 2 and 3).

\section{Feedback (retro-información)}

CIALs and GETs have a final event where the farmerexperimenters explain their preferences for each technology. But INNOVA used this feedback (during all three years) to encourage farmers to suggest changes in the technologies and plan the next year. The farmer-experimenters and the agronomists outline key points the day before on a large sheet of paper, which the farmers present in their own words.

Discussions with the audience often helped improve the technology. For example in Pomposillo, on the Altiplano, people said it was important to plough, adding that the grains-plus-legumes failed in 2003 (year one) because they were planted late. INNOVA followed their recommendations and in 2005 (year three), the oats- 
(a)

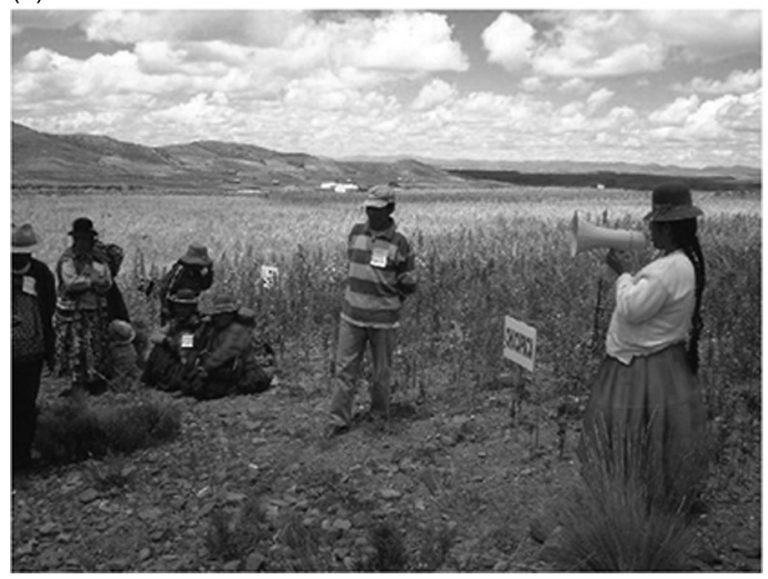

(b)

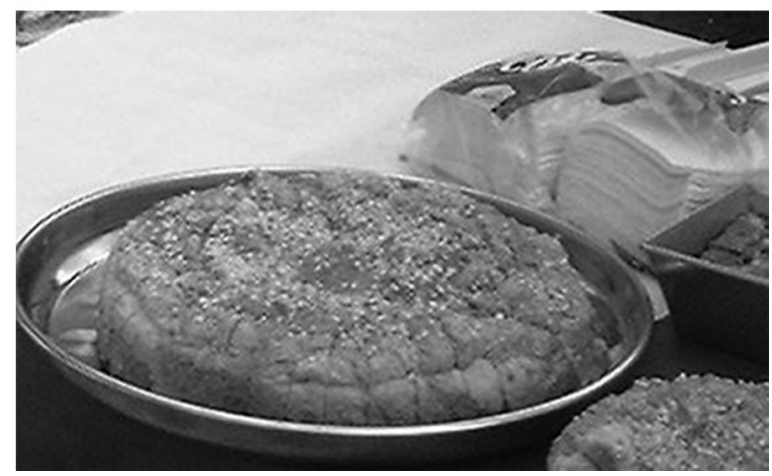

Figure 1 It was hard to compete with quinoa in the technology fair in Pomposillo, with a thriving crop explained in Aymara (a) followed by cake (b). Presentation matters as does demand

plus-vetch on the Altiplano were tall and green for the technology fair, and visiting farmers wanted to plant the mix (see Figure 4).

During the feedback in Sank'ayani, in the high valleys of Cochabamba, farmers said they liked vetch, but they would like it more if the seed were not so expensive. They proposed trials to grow their own vetch seed. INNOVA started doing trials with farmers to grow seed.

\section{MIPITA}

SIBTA uses an extension method called PITAs (applied technology innovation projects) where agronomists extend technology to organized groups, especially associations (tomato growers,

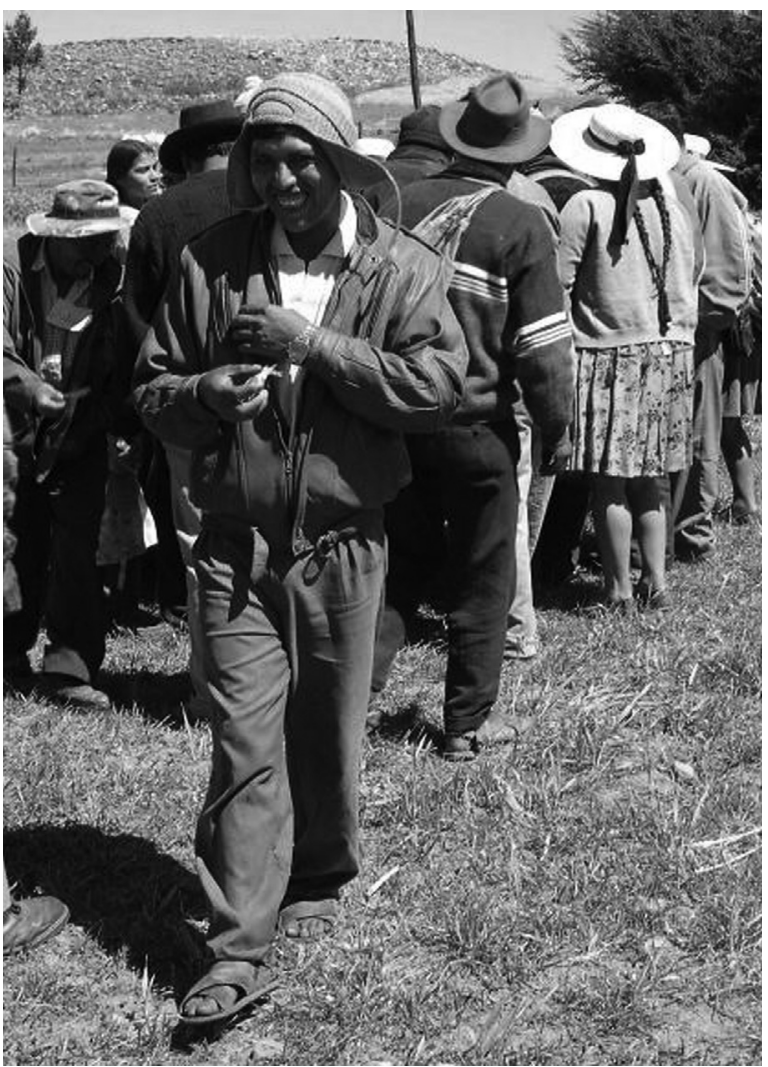

Figure 2 People like to experiment. Farmers at the technology fair in 2003 in Qhochimit'a rush to get $50 \mathrm{~g}$ bags of alfalfa seed, which they can plant at home

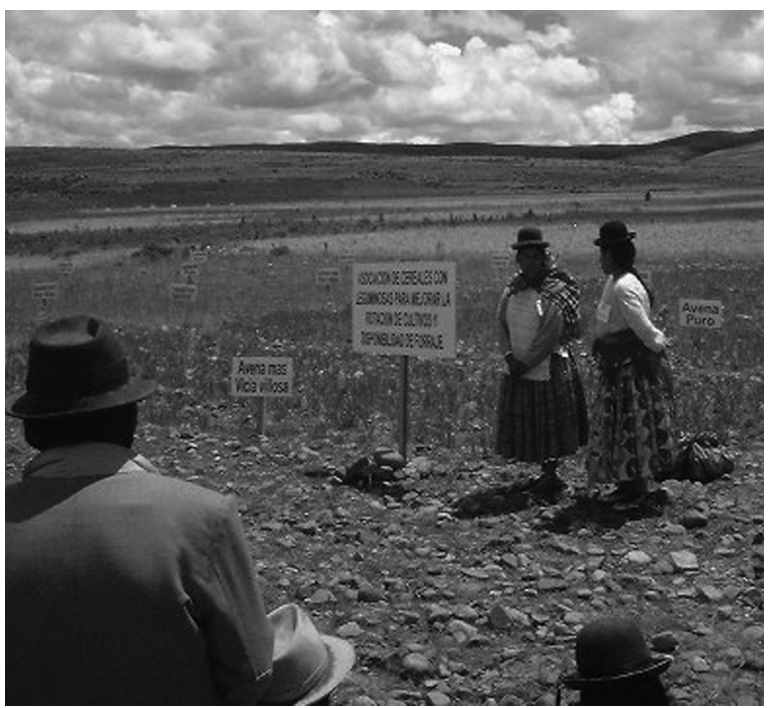

Figure 3 An innovation is more convincing if it is shown in a thriving crop. In 2003 the grains-plus-legume mixes grew poorly on the Altiplano, seen here in the technology fair 


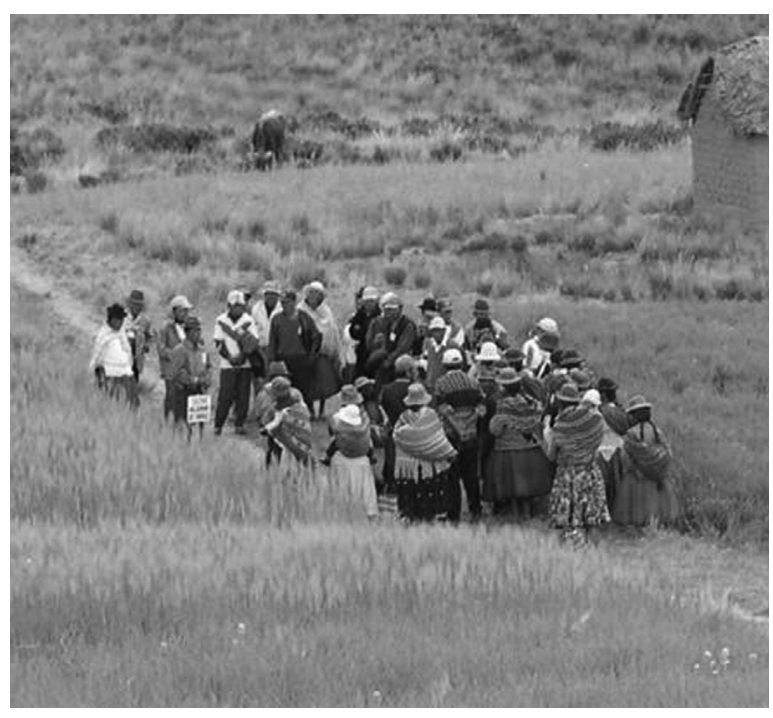

Figure 4 Technology fair, 2005 in Kellhuiri, on the Altiplano. Humberto Cachaca shows the barley-\&-vetch he grew with the MIPITA. The mix grew better than in 2003, thanks to suggestions made by farmers in the GET. Now the visitors wanted to try the idea

onion growers etc.) usually linked to market opportunities. In its third year, INNOVA created the MIPITA (INNOVA model of PITAS) to extend the most promising technologies and to adjust methods to link technology supply and demand. INNOVA funded and implemented three MIPITAs, one in each pilot area. Some MIPITAs included several communities and were organized (for example) to buy seeds, so people could adopt forages.

As Table 4 shows, INNOVA made the effort to use various formal methods to gauge farmer demand in an integrated way. The methods themselves evolved over time (e.g. the sondeo gave rise to the stratified sondeo, and the technology fair improved every year).

While the Bolivian farmers happily agreed to take part in semi-structured interviews, questionnaires and other formal methods, researchers learned at least as much from farmers incidentally, simply by working with them in the field trials. For example, while spreading dry chicken manure with farmers in the low valleys, agronomist Ernesto Montellano saw that the manure got in people's eyes, and it burned. The farmers suggested placing the manure in the bottom of the furrow instead of scattering it over the surface, which they did, and that became the technical recommendation. Unfortunately, their university training usually does not prepare researchers to write about conversations held on ditch banks or while following an ox team around a field. The following section tries to remedy that by recapturing some of the lessons that farmers and agronomists learned, with formal methods, and informally.

\section{Case studies}

\section{From improved fallow to purple clover}

This technology did address explicit demand, even so it changed a great deal as the farmer-experimenters and the agronomists adapted it. Purple clover (Trifolium pratense) has been in Bolivia since the 1970s, when it was introduced by earlier projects. PROMETA tried planting mixes of purple clover, white clover ( $T$. repens) and vetch (Vicia sativa) with various grasses (Lolium, Festuca, Dactylis, Eragrostis curvula and Bromus unioloides) in farmers' fields in Qolqe Qhoya and elsewhere in the high valleys of Cochabamba in 1996.

After 2000, another project, PROMMASEL, inherited purple clover from PROMETA and continued trying it in Qolqe Qhoya. PROMMASEL started with botanical and ethno-botanical surveys. After planting potatoes, farmers typically plant other crops for two or three years, and end with oats or barley; then fallow the land. Weeds build up each year, and are abundant in the first few years of fallow, although many of the weeds are fodder for livestock. Several of the authors were involved with a study of weeds (Bentley et al., 2005), and we thought that the fallow could be improved by planting purple clover and other plants. So for several years PROMMASEL conducted on-farm trials of 'improved fallow', mixes of grasses and legumes.

During the first sondeo in November 2002 in Qolqe Qhoya, people said they were tired of doing little field trials with clover. 'We want to try big fields', they said. INNOVA agronomist Salomón Pérez dutifully returned four days later and tried selling the seed at a meeting of the sindicato (village organizations with elected leaders and a monthly meeting with a representative from each household). Pérez even went door to door, and still only four families bought purple clover seed. In 
Table 4 Evolution of methods

\begin{tabular}{|c|c|c|c|c|}
\hline & $\begin{array}{l}\text { Before INNOVA: } \\
\text { 1990s-2001 }\end{array}$ & $\begin{array}{c}\text { INNOVA Year 1: } \\
2002-03\end{array}$ & $\begin{array}{c}\text { INNOVA Year 2: } \\
2003-04\end{array}$ & $\begin{array}{l}\text { INNOVA Year 3: } \\
2004-05\end{array}$ \\
\hline Methods used & $\begin{array}{l}\text { CIAT and PROINPA } \\
\text { used CIALs } \\
\text { CIAT did sondeos. } \\
\text { UMSS held field } \\
\text { days. PROINPA had } \\
\text { on-farm trials \& field } \\
\text { days, led by farmers } \\
\text { from FFS }\end{array}$ & $\begin{array}{l}\text { CIALs \& GETs. } \\
\text { Sondeos \& } \\
\text { technology fairs in } \\
\text { the } 3 \text { zones. } \\
6 \text { feedbacks, } 2 \text { per } \\
\text { zone }\end{array}$ & $\begin{array}{l}\text { CIALs and GETs } \\
\text { continued. } \\
\text { Back-\&-forth. } \\
4 \text { stratified sondeos. } \\
\text { Technology fairs in } \\
\text { high \& low valleys }\end{array}$ & $\begin{array}{l}\text { INNOVA formed } \\
\text { MIPITAs. } \\
\text { Technology fair on } \\
\text { the Altiplano \& the } \\
\text { high valleys }\end{array}$ \\
\hline $\begin{array}{l}\text { Results of } \\
\text { methods }\end{array}$ & & $\begin{array}{l}\text { Showed that there } \\
\text { was demand for } \\
\text { most technologies } \\
\text { created by earlier } \\
\text { projects, but that } \\
\text { other demands } \\
\text { were not being met. } \\
\text { Staff doubted that } \\
\text { the project reached } \\
\text { the poorest farmers, } \\
\text { and planned a } \\
\text { stratified sondeo }\end{array}$ & $\begin{array}{l}\text { Some demands are } \\
\text { shared by all } \\
\text { economic levels, } \\
\text { but in all } 3 \text { zones, } \\
\text { the poorer farmers } \\
\text { do have different } \\
\text { demands }\end{array}$ & $\begin{array}{l}\text { INNOVA presented } \\
\text { the technologies in } \\
\text { a way that } \\
\text { smallholder farmers } \\
\text { understood. Some } \\
\text { technologies began } \\
\text { to be adopted }\end{array}$ \\
\hline Technical results & $\begin{array}{l}\text { Research started on } \\
\text { most technologies } \\
\text { that INNOVA would } \\
\text { promote }\end{array}$ & $\begin{array}{l}\text { Improved phalaris, } \\
\text { oat-plus-vetch, } \\
\text { purple clover \& } \\
\text { other technologies }\end{array}$ & $\begin{array}{l}\text { Developed multiple } \\
\text { mountain plough, } \\
\text { high tillage, soap to } \\
\text { manage insects in } \\
\text { potatoes }\end{array}$ & $\begin{array}{l}\text { Control of potato } \\
\text { tuber moth in } \\
\text { storage }\end{array}$ \\
\hline
\end{tabular}

other words, they had explicitly demanded seed, and then showed little interest in buying it. Some said they did not have the money. Others said they would wait to see their neighbours plant it first.

INNOVA kept studying 'improved fallow' and in the first technology fair, in Qolqe Qhoya, presented a participatory trial, in a farmer's field, with three treatments of different mixes. But at the same technology fair, another farmer, Nelson Vallejos, showed a plot of about 1000 square meters he had planted on his own (see Figure 5). As soon as Vallejos and the others started planting purple clover on their own, they changed it radically. Instead of planting it at harvest time, they planted it at the regular planting time, and they sowed it with oats, instead of with festuca or lolium, since they knew oats better, and had the seed. They planted purple clover in good soil, not in hillside fields. INNOVA recommended another change, irrigation. Farmers and agronomists realized that they should plough carefully when planting, instead of simply broadcasting the seed. Later farmers began manuring the clover (see Figure 6).
The members of the GET mentioned these changes at the first feedback in Qolqe Qhoya, and with the agronomists, redesigned purple clover so it yielded fodder, which was what they demanded.

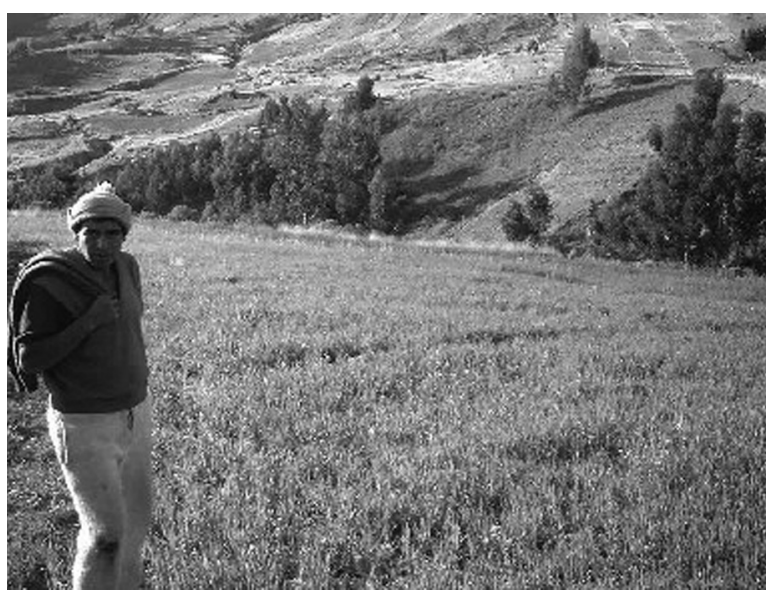

Figure 5 Nelson Vallejos, 2003 in his plot of purple clover 


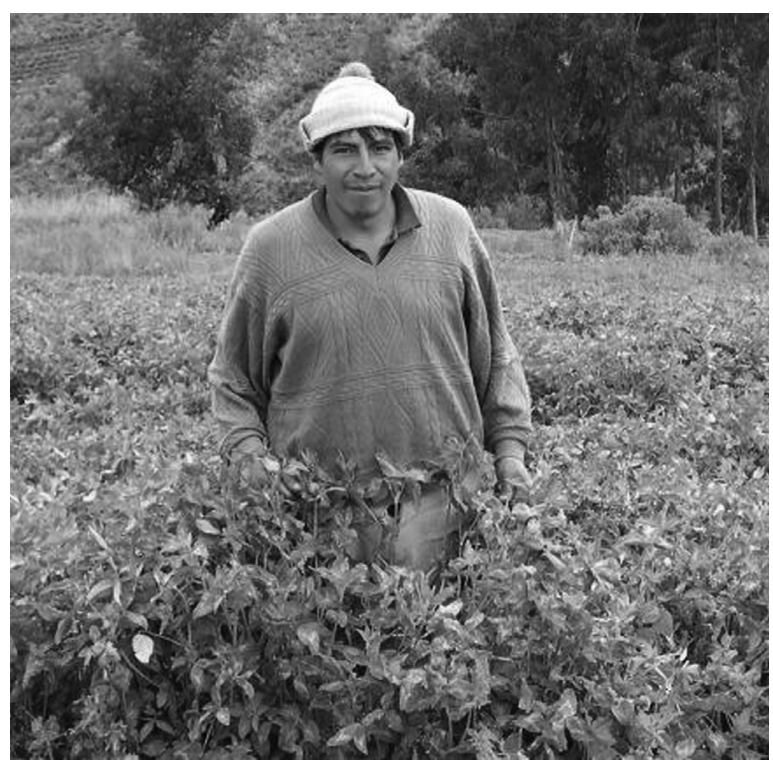

Figure 6 The same plot in 2005

Mr Vallejos and the others in the GET may well have benefited from their five or six years' experience with purple clover and other fodders during earlier projects, but they made big changes in the technology once they began planting purple clover on their own. It has long been known that farmers modify what they learn (Johnson, 1972; Denevan, 1983); the advantage here was having the agronomists there to see what the farmers were doing, and collect some hard data. This way the agronomists themselves accepted the changes, and would later recommend them to other farmers.

By 2005 the MIPITA in the high valleys helped 17 farmers from various communities get 36 kilos of purple clover seed, enough to plant small parcels on their own. At the technology fair in 2005, Nelson Vallejos once again showed his small plot of clover, only this time the sign did not say 'improved fallow'. It said 'managing purple clover', because farmers and agronomists realized that the technology had changed from a type of fallow to a kind of permanent pasture. INNOVA even printed pamphlets for farmers, describing the purple clover as pasture.

\section{Phalaris grass}

The above case suggests that farmers and researchers working together may make major changes in a technology. But change is not always so dramatic. Sometimes the researchers create appropriate technology essentially on their own, in response to explicit demand, later making only minor adjustments with farmer-colleagues.

1970s. IBTA introduced a small lot of phalaris from Colombia to the experimental station at Patacamaya, on the Altiplano, as forage (Mendieta, 1979). The agronomists lost interest in phalaris, but the hardy grass survived anyway. In the early 1980s, CIF promoted it in the valleys and high country of Cochabamba.

1996-99. The Hillsides Projects (PROLADE) rediscovered phalaris and tried it for live barriers to conserve soil in Cochabamba and Santa Cruz. The grass thrived and farmers and NGOs started to accept it.

In December 2002, INNOVA took phalaris to the Altiplano. At first, proposing it as a live barrier, looking for small slopes to plant it on. The GETs in Pomposillo and Mamaniri planted live barriers and 40 people took plants.

2003. During the technology fair in Pomposillo the phalaris grass was still only three months old, and not well established yet, so INNOVA decided not to show it. Two farmers explained phalaris in a stand, and gave away a few plants. But five months later, 16 August 2003, when the phalaris was better grown, they presented it again in Pomposillo at the feedback, and six people asked where they could get more.

In December 2003, INNOVA sold 10,300 phalaris plants to 66 households in six communities (two in each pilot area). In participatory evaluations in the GETs people had only good things to say about phalaris: It stayed green after frosts. It was easy to transplant, took root readily, grew back well after being cut, was cheap to establish, animals liked to eat it and it even kept the Andean potato weevil out of the fields (see Figure 7).

2004. INNOVA started the forage MIPITA in the Altiplano and 71 households bought 18,500 plants. The GETs made one change; they no longer planted phalaris as a live barrier, but in open fields, on flat land, as forage.

2005. INNOVA introduced the idea of making hay from phalaris, and 130 families tried it. In the technology fair at Kellhuiri, Umala, farmers Javier Condori and Gladys Condori gave a glowing account of phalaris. Even though they spoke at a 
stand, not in a field, people in the crowd asked 'Where can I get it to plant?'

\section{High hilling up}

In the first two cases, the technologies were adapted to fit an explicit demand. But in this next case, the farmers did not ask for the technology; it responded to an implicit demand, and through a sustained conversation changed it into an explicit one.

2000. The MIPAPA Project started a scientific survey of pests and diseases in the low valleys (Santa Cruz).

April 2001. In Comarapa, Santa Cruz, CIAT found the small beetle Epitrix damaging seed potato in the CIAL in Verdecillos. Agronomist Ernesto Montellano, Pablo Franco and colleagues decided to try managing it with a technique they had learned from CIP: higher aporque (hilling up: after potatoes sprout, farmers heap soil up onto the plants as they weed). But it was hard to do well with a wooden plough.

2002. People in the CIALs and GETs started using a higher aporque. Previously, they had heaped the soil when the potatoes were big, which damaged many tubers. Now, they heaped the soil just as the plants were sprouting, and again when the plants had grown but the tubers were still small. This damaged the potato plants less and gave room in the soil for the tubers to bulk up. INNOVA

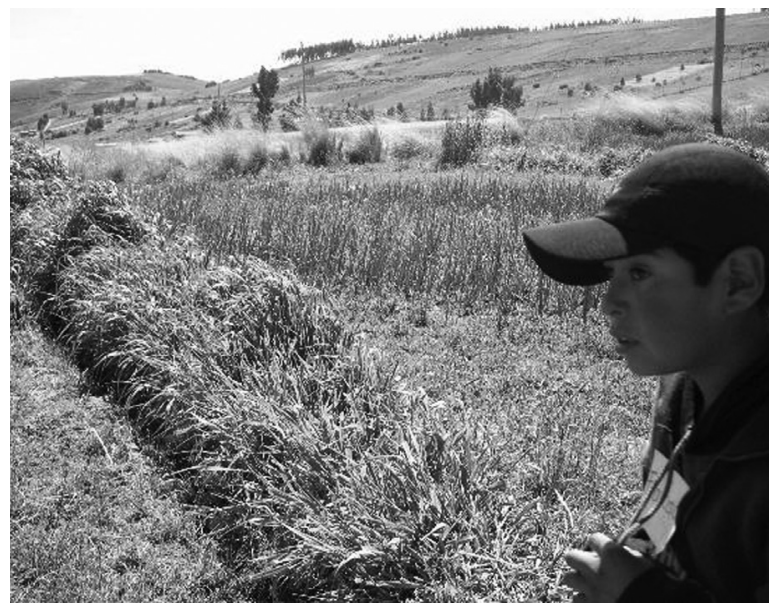

Figure $7 \mathrm{~A}$ thick row of phalaris in the high valleys of Cochabamba planted tillage trials in all three areas, and showed them at the technology fairs.

2003. The PROMETA agronomists came to Comarapa and designed a plough with wings, with the CIAL, using Back-\&-Forth, and showed the plough and trials at the technology fairs (see Figure 8).

2004-05. INNOVA taught high hilling up in the MIPITA, to 80 families. The new plough lowered costs, because it was faster. Yields increased 15$20 \%$, in part because there was less tuber moth, weevil and Epitrix. People also liked it on the Altiplano and in the high valleys. 'The potatoes don't turn green and there are more large potatoes.' In the technology fair in Kellhuiri on the Altiplano, in 2005, farmer-experimenter Rogelio Cachaca López showed how he had doubled his potato harvest, among other things, by using high hilling up.

\section{Conclusions}

All of the INNOVA technologies changed as they responded to demand, but in different ways. After years of working with scientists on purple clover, farmers made several big changes, which they never would have made if researchers had not shared the crop with farmers. Phalaris changed much less; after scientists introduced it farmers made only one change, planting it in small fields instead of in live barriers. Researchers accepted this in good faith, and responded with a further

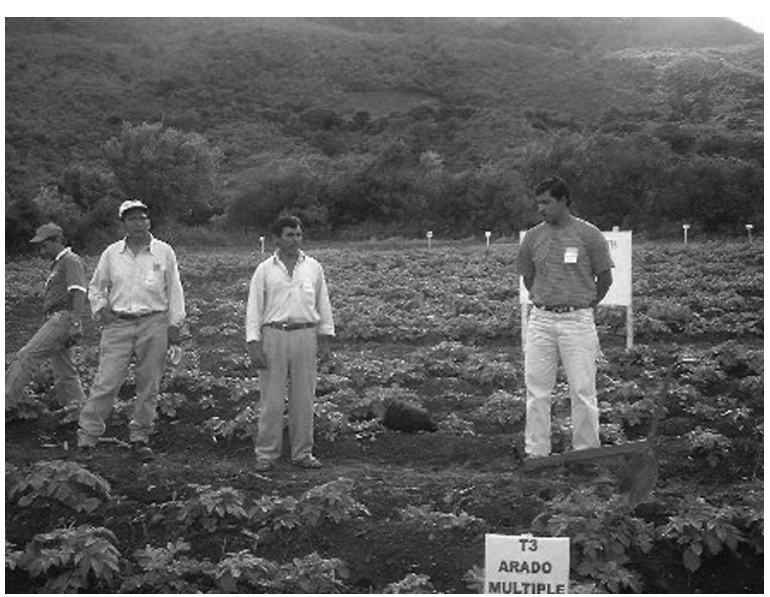

Figure 8 High hilling up and the new plough at the technology fair in Verdecillos, Comarapa, Santa Cruz, 2003 
change of their own: making hay from phalaris. High aporque (hilling up) was researcher-led, and did not respond to an explicit demand; it was invented by CIP researchers to grow bigger potatoes, but bigger potatoes are not always what Andean farmers demand (Zimmerer, 2003). Furthermore, while adapting high aporque to Bolivia, researchers made most of the changes, although they did all of their trials with farmers, who then accepted the technology.

Perhaps the clearest evidence that INNOVA responded to demand was that it had the honesty to end fruitless lines of research (two out of 10 in
Table 5) and that technologies evolved as the conversation with farmers was developed (eight out of 10 in Table 5). INNOVA's methods contributed to the conversation and the changes (all 10 in Table 5), although as we mentioned earlier, spending time with farmers and looking and listening were equally important.

Demand for innovation is not a static phenomenon which can be discovered and then acted upon. Demand co-evolves with research, and must be monitored as the technologies develop; that is how commercial products are developed, either with focus groups or with individuals (Morgan,

Table 5 Changes in technologies and the methods that influenced the change

\begin{tabular}{|c|c|c|c|}
\hline Technology & How it changed & Where & Methods involved \\
\hline 1. Improved fallow & $\begin{array}{l}\text { Adopted as forage, not as } \\
\text { improved fallow }\end{array}$ & Low and high valleys & $\begin{array}{l}\text { Technology fair, GET, } \\
\text { feedback }\end{array}$ \\
\hline 2. Grains-plus-legumes & $\begin{array}{l}\text { Farmers like it, if they can } \\
\text { produce vetch seed, but } \\
\text { few are actually growing it }\end{array}$ & High valleys & $\begin{array}{l}\text { GET, feedback, } \\
\text { technology fair, MIPITA }\end{array}$ \\
\hline 3. New fodders & $\begin{array}{l}\text { Included with } \\
\text { technologies } 1,2 \text { and } 4\end{array}$ & $\begin{array}{l}\text { Being diffused in high } \\
\text { valleys, with subsidized } \\
\text { seed }\end{array}$ & $\begin{array}{l}\text { Technology fair, GET, } \\
\text { CIAL, MIPITA }\end{array}$ \\
\hline 4 Phalaris grass & $\begin{array}{l}\text { Planted for fodder, not for } \\
\text { soil conservation }\end{array}$ & $\begin{array}{l}\text { Being adopted, especially } \\
\text { on the Altiplano and in the } \\
\text { high valleys }\end{array}$ & $\begin{array}{l}\text { Feedback, GET, } \\
\text { technology fair }\end{array}$ \\
\hline $\begin{array}{l}\text { 5. Chicken manure for } \\
\text { nematodes }\end{array}$ & $\begin{array}{l}\text { Place the manure in the } \\
\text { bottom of the furrow } \\
\text { instead of broadcasting it, } \\
\text { to keep it out of one's } \\
\text { eyes }\end{array}$ & $\begin{array}{l}\text { Being adopted in low } \\
\text { valleys }\end{array}$ & CIAL \\
\hline 6. Potato IPM & $\begin{array}{l}\text { Soap and detergent to } \\
\text { control insect vectors. } \\
\text { Fungicides and } \\
\text { insecticides are still under } \\
\text { study. Control of moths in } \\
\text { seed }\end{array}$ & $\begin{array}{l}\text { In diffusion in the low } \\
\text { valleys }\end{array}$ & $\begin{array}{l}\text { GET, CIAL, MIPITA, } \\
\text { technology fair }\end{array}$ \\
\hline $\begin{array}{l}\text { 7. Herbicide for purple nut } \\
\text { sedge }\end{array}$ & $\begin{array}{l}\text { Glyphosate used by } \\
\text { farmers, but new lines of } \\
\text { research to refine } \\
\text { application methods were } \\
\text { abandoned }\end{array}$ & & Technology fair \\
\hline 8. Improved tillage & $\begin{array}{l}\text { Invented high tillage, and } \\
\text { a new plough to do it with }\end{array}$ & Adopted in low valleys & $\begin{array}{l}\text { Technology fair GET, } \\
\text { MIPITA, CIAL }\end{array}$ \\
\hline $\begin{array}{l}\text { 9. Adoption of } \\
\text { implements }\end{array}$ & $\begin{array}{l}\text { Extended implements, } \\
\text { but also invented the } \\
\text { multiple mountain plough }\end{array}$ & High and low valleys & $\begin{array}{l}\text { Back-\&-forth, GET, CIAL, } \\
\text { technology fair, MIPITA }\end{array}$ \\
\hline $\begin{array}{l}\text { 10. Home remedies for } \\
\text { cows }\end{array}$ & Abandoned & & $\begin{array}{l}\text { Technology fair, short } \\
\text { courses in communities }\end{array}$ \\
\hline
\end{tabular}


1997; Bernet et al., 2005), even with interviews in consumers' homes (Sunderland et al., 2004).

Successful innovation is not the work of solitary heroes, but of groups and institutions, linked in relationships of trust, where the users can make their demands known and be involved in the research (Barnett, 2004). Innovation, like conversation, goes in stages. This brings us back to two concerns posed at the beginning of this paper.

First, capturing farmer demand may not be as simple as some policy makers suppose. Gauging demand requires more than a petition from farmers. Demands are of different types: explicit demands can be more easily captured than implicit ones. Farmers may voice explicit demands, and researchers may have to intuit some of the implicit ones. Researchers respond with some technology, although even the strongest research institutes would be unlikely to meet all of farmers' demands. The farmers then respond to the new 'supply' of technology, which researchers must then adapt to an increasingly focussed, more sophisticated set of demands. Appropriate methods such as the sondeo, technology fair and others, particularly when ordered into a coherent set, help to guide the evolution of supply and demand, but just as important are the insights that come from working closely with farmers.

Second, what should be done with research that is already underway and in which a high investment has already been made? In this case, most, but not all, the technology generated by the previous projects responded to either an explicit demand or to an implicit one. Throwing away existing technologies and starting from scratch would have scuttled potentially functional technology, wasting a research investment and potential for helping poor farmers in Bolivia and elsewhere.

\section{Acknowledgements}

This publication is an output from research projects funded by the United Kingdom Department for International Development (DFID) through its RNRRS (Renewable Natural Resources Research Strategy) for the benefit of developing countries, and through the CPP (Crop Protection Research Programme), LPP (Livestock Production Programme) and CPHP (Crop Post-Harvest Research Programme). The views expressed are not necessarily those of DFID. The authors are grateful for the support of the SDC who fund Papa Andina, and who have given generous support to PROINPA; without which INNOVA would not have been possible. A hearty thanks to the farmer-experimenters, those mentioned in the text and all the others who helped the researchers develop the technologies discussed here. Thanks to Brian Sims, Jim Waller, Phil Jones and other scientists who started much of the work with these technologies, to Antonio Gandarillas for moral support and guidance of the research and to Frances Kimmins who read and commented on an earlier version of this paper. Doug Horton helped us to clarify some of our concepts of farmer demand.

The INNOVA team (in alphabetical order by first name)

\begin{tabular}{||l|l||}
\hline \hline Institution & \multicolumn{1}{|c||}{ People } \\
\hline Leadership, Papa & André Devaux, \\
Andina (CIP); & Claudio Velasco, Graham \\
DFID CPP (NRIL) & Thiele \\
\hline CIAT/Santa Cruz & Alan Barrero, Bertho \\
Villarroel, Ernesto \\
Montellano, Guillermo \\
Beltman, Henry \\
Tardío, Pablo Franco, \\
Ramiro Rojas, Steve Eguino
\end{tabular}




\section{References}

Ashby, J.A. (1992) Manual para la Evaluación de Tecnología con Productores. Cali, Colombia: CIAT, Proyecto IPRA.

Ashby, J., Braun, A.R., García, T., Guerrero, M.P., Hernández, L.A., Quirós, C.A. and Roa, J.I. (2000) Investing in Farmers as Researchers: Experience with Local Agricultural Committees in Latin America. Cali, Colombia: CIAT.

Barnett, A. (2004) From 'Research' to Poverty Reducing 'Innovation'. Brighton, UK: Sussex Research Associates, Ltd. On WWW at http://www.cphp.uk.com/ uploads/disseminations/NSIPolicyBriefbrochure23 feb04.pdf. Accessed 07.05.07.

Bellon, M.R. (2001) Participatory Research Methods for Technology Evaluation: A Manual for Scientists Working with Farmers. Mexico City: CIMMYT.

Bellon, M.R. (2002) Analysis of the demand for crop characteristics by wealth and Gender: A case study from Oaxaca, Mexico. In M.R. Bellon and J. Reeves (eds) Quantitative Analysis of Data from Participatory Methods in Plant Breeding (pp. 66-81). Mexico, DF: CIMMYT.

Bentley, J.W., Boa, E., Van Mele, P., Almanza, J., Vasquez, D. and Eguino, S. (2003) Going public: A new extension method. International Journal of Agricultural Sustainability 1 (2), 108-123.

Bentley, J.W., Thiele, G., Oros, R. and Velasco, C. (2004) Cinderella's Slipper: Sondeo Surveys and Technology Fairs for Gauging Demand. London: ODI Agricultural Research \& Extension Network (AgREN). Network Paper No. 138.

Bentley, J.W., Webb, W., Nina, S. and Pérez, S. (2005) Even useful weeds are pests: Ethnobotany in the Bolivian Andes. International Journal of Pest Management 51 (3), 189-207.

Bernet, T., Devaux, A., Ortiz, O. and Thiele, G. (2005) Participatory market chain approach. BeraterInnen News 1: 1-6.

Beye, G. (2002) Impact of Foreign Assistance on Institutional Development of National Agricultural Research Systems in Sub-Saharan Africa. Rome: FAO Research and Technology Paper 10.111 pp.

Braun, A., Thiele, G. and Fernández, M. (2000) Farmer field schools and local agricultural research committees: Complementary platforms for integrated decision-making in sustainable agriculture. ODI Agricultural Research \& Extension Network (AgREN). Network Paper No. 105.

Bunch, R. (1982) Two Ears of Corn: A Guide to PeopleCentered Agricultural Improvement. Oklahoma City: World Neighbors. 250 pp.

Byerlee, D. (1998) The search for a new paradigm for the development of national agricultural research systems. World Development 26 (26), 1049-1056.

Dalrymple, D.G. (2005) Scientific knowledge as a global public good: Contributions to innovation and the economy. In J.M. Esanu and P.F. Uhlir (eds) The
Role of Scientific and Technical Data and Information in the Public Domain: Proceedings of a Symposium (pp. 35-51). The National Academies Press, Washington, D.C. 2003.

Denevan, W.M. (1983) Adaptation, variation, and cultural geography. The Professional Geographer 35 (4), 399-407.

Gandarillas, A., Blajos, J., Devaux, A. and Thiele, G. (2007). Changing paradigms for organizing R \& D: Agricultural research and the creation of the PROINPA Foundation in Bolivia. International Journal of Agricultural Resources, Governance, and Ecology 6 (2), 256-276.

German, L.A., Kidane, B. and Mekonnen, K. (2005) Watershed Management to Counter Farming Systems Decline: Toward a Demand-Driven, Systems-Oriented Research Agenda. London: ODI Agricultural Research \& Extension Network (AgREN). Network Paper No. 145.

Gill, G. (2002) Applications of Appropriate Agricultural Technology and Practices and Their Impact on Food Security and the Eradication of Poverty: Lessons Learned from Selected Community Based Experiences. London: ODI Food Security Briefings 3.

Grandin, B.E. (1988) Wealth Ranking in Smallholder Communities: A Field Manual. London: Intermediate Technology Publications. 49 pp.

Hall, A., Sulaiman, R, Clark, N. and Yoganand, B. (2003) From measuring impact to learning institutional lessons: an innovation systems perspective in improving the management of international agricultural research. Agricultural Systems 78, 213-241.

Hildebrand, P.E. (1981) Combining disciplines in rapid appraisal: The sondeo approach. Agricultural Administration 8, 423-432.

Horne, P. and Stür, W.W. (2005) Developing agricultural solutions with smallholder farmers: How to get started with participatory approaches. In J. Gonsalves, T. Becker, A. Braun, D. Campilan, H. de Chavez, E. Fajber, M. Kapiriri, J. Rivaca-Caminade and R. Vernooy (eds) Participatory Research and Development for Sustainable Agriculture and Natural Resource Management: A Sourcebook (Vol. 1, pp. 172-180). Manila: CIP-Upward/IDRC.

Johnson, A.W. (1972) Individuality and experimentation in traditional agriculture. Human Ecology 1 (2), $149-159$

Mayer, E. (2002) The Articulated Peasant: Household Economics in the Andes. Boulder, Colorado: Westview Press. 390 pp.

Mendieta, H. (1979) Introducción del pasto brasilero (Phalaris sp.). In VI Reunión Nacional de Pastos y Forrajes y IV Reunión Nacional de Ganadería ABOPAIBTA-INFOL (pp. 131-132). Trinidad, septiembre 1979. Bolivia $440 \mathrm{pp}$.

Morgan, D.L. (1997) Focus Groups as Qualitative Research (2nd edn). London: Sage Publications. 88 pp.

Pretty, J. (2002) Agri-Culture: Reconnecting People, Land and Nature. London: Earthscan. 261 pp. 
Quiroga, J.A., Tapia, O., Llanos, L. and Sandoval, Y. (1999) Bolivia un Mundo de Potencialidades: Atlas Estadístico de Municipios. La Paz: Instituto Nacional de Estadística, Ministerio del Desarrollo Sostenible y Planificación, Swiss Agency for Development and Cooperation.

Royal Society (2004) Royal Society Response to the Department for International Development Consultation on the Research Funding Framework 2005-7. London: Policy document 18/04.

Smale, M. and De Groote, H. (2003) Diagnostic research to enable adoption of transgenic crop varieties by smallholder farmers in sub-Saharan Africa. African Journal of Biotechnology 2 (12), 586-595.

Sunderland, P.L., Taylor, E.G. and Denny, R.M. (2004) Being Mexican and American: Negotiating ethnicity in the practice of market research. Human Organization 63 (3), 373-380.

Thiele, G. and Terrazas, F. (1998) The wayq'os (gullies) are eating everything! Indigenous knowledge and soil conservation. PLA Notes 32, 19-23.
Thiele, G., Braun, A. and Gandarillas, E. (2005) Farmer field schools and local agricultural research committees as complementary platforms. In J. Gonsalves, T. Becker, A. Braun, D. Campilan, H. de Chavez, E. Fajber, M. Kapiriri, J. Rivaca-Caminade and R. Vernooy (eds) Participatory Research and Development for Sustainable Agriculture and Natural Resource Management: A Sourcebook (Vol. 3, pp. 142-152). Manila: CIP-Upward/IDRC.

Tudge, C. (2004) So Shall We Reap. London: Penguin Books. 451 pp.

Van Mele, P. and Van Chien, H. (2004) Farmers, biodiversity and plant protection: Developing a learning environment for sustainable tree cropping systems. International Journal of Agricultural Sustainability 2 (1), 67-76.

Zimmerer, K.S. (2003) Just small potatoes (and ulluco)? The use of seed-size variation in 'native commercialized' agriculture and agrobiodiversity conservation among Peruvian farmers. Agriculture and Human Values 20 (2), 107-123. 